\title{
Front Matter: Volume 11902
}

, "Front Matter: Volume 11902," Proc. SPIE 11902, Real-time Photonic Measurements, Data Management, and Processing VI, 1190201 (15 November 2021); doi: 10.1117/12.2619352

SPIE. Event: SPIE/COS Photonics Asia, 2021, Nantong, Jiangsu, China 


\title{
PROCEEDINGS OF SPIE
}

\section{Real-time Photonic Measurements, Data Management, and Processing VI}

\author{
Ming Li \\ Bahram Jalali \\ Mohammad Hossein Asghari \\ Editors
}

\section{0-12 October 2021 \\ Nantong, China}

Sponsored by

SPIE

COS-Chinese Optical Society

Cooperating Organizations

Tsinghua University (China) - Peking University (China) - University of Science and Technology of China (China) • Zhejiang University (China) • Tianjin University (China) Beijing Institute of Technology (China) • Beijing University of Posts and Telecommunications (China) - Nankai University (China) • Changchun University of Science and Technology (China) - University of Shanghai for Science and Technology (China) • Capital Normal University (China) - Huazhong University of Science and Technology (China) • Beijing Jiaotong University (China) - China Jiliang University (China) - Shanghai Institute of Optics and Fine Mechanics, CAS (China) - Changchun Institute of Optics, Fine Mechanics and Physics, CAS (China) - Institute of Semiconductors, CAS (China) - Institute of Optics and Electronics, CAS (China) - Institute of Physics, CAS (China) Shanghai Institute of Technical Physics, CAS (China) • China Instrument and Control Society (China) The Optical Society of Japan (Japan) • Optical Society of Korea (Korea, Republic of) • Australia and New Zealand Optical Society (Australia) - Optics and Photonics Society of Singapore (Singapore) • European Optical Society

\section{Supporting Organizations}

China Association for Science and Technology (CAST) (China) - Department of Information of National Nature Science Foundation, China (NSFC) (China)

\section{Published by}

SPIE

\section{Volume 11902}


The papers in this volume were part of the technical conference cited on the cover and title page. Papers were selected and subject to review by the editors and conference program committee. Some conference presentations may not be available for publication. Additional papers and presentation recordings may be available online in the SPIE Digital Library at SPIEDigitalLibrary.org.

The papers reflect the work and thoughts of the authors and are published herein as submitted. The publisher is not responsible for the validity of the information or for any outcomes resulting from reliance thereon.

Please use the following format to cite material from these proceedings:

Author(s), "Title of Paper," in Real-time Photonic Measurements, Data Management, and Processing VI, edited by Ming Li, Bahram Jalali, Mohammad Hossein Asghari, Proc. of SPIE 11902, Seven-digit Article CID Number (DD/MM/YYYY); (DOI URL).

ISSN: 0277-786X

ISSN: 1996-756X (electronic)

ISBN: 9781510646537

ISBN: 9781510646544 (electronic)

Published by

SPIE

P.O. Box 10, Bellingham, Washington 98227-0010 USA

Telephone +1 3606763290 (Pacific Time)

SPIE.org

Copyright (C) 2021 Society of Photo-Optical Instrumentation Engineers (SPIE).

Copying of material in this book for internal or personal use, or for the internal or personal use of specific clients, beyond the fair use provisions granted by the U.S. Copyright Law is authorized by SPIE subject to payment of fees. To obtain permission to use and share articles in this volume, visit Copyright Clearance Center at copyright.com. Other copying for republication, resale, advertising or promotion, or any form of systematic or multiple reproduction of any material in this book is prohibited except with permission in writing from the publisher.

Printed in the United States of America by Curran Associates, Inc., under license from SPIE.

Publication of record for individual papers is online in the SPIE Digital Library.

\section{SPIE. DIGITAL}

Paper Numbering: A unique citation identifier (CID) number is assigned to each article in the Proceedings of SPIE at the time of publication. Utilization of CIDs allows articles to be fully citable as soon as they are published online, and connects the same identifier to all online and print versions of the publication. SPIE uses a seven-digit CID article numbering system structured as follows:

- The first five digits correspond to the SPIE volume number.

- The last two digits indicate publication order within the volume using a Base 36 numbering system employing both numerals and letters. These two-number sets start with 00, 01, 02, 03, 04, 05, 06, 07, 08, 09, 0A, OB ... 0Z, followed by 10-1Z, 20-2Z, etc. The CID Number appears on each page of the manuscript. 


\section{Contents}

IMAGING AND SENSING I

1190202 Temporal focusing based ultrafast high-resolution spectroscopy (Invited Paper) [1 1902-1]

1190203 Proposal of real-time Brillovin optical fiber sensing based on compressing sensing and pattern recognition algorithms (Invited Paper) [1 1902-7]

1190204 Brillouin optical fiber sensing via optical chirp chain for ultrafast distributed measurement (Invited Paper) [1 1902-3]

IMAGING AND SENSING II

1190206 Increase measurement range, distance, and speed of optical fiber distribution acoustic sensing (Invited Paper) [11902-5]

$1190207 \quad$ High-resolution 3D range gated laser imaging for unmanned underwater vehicles (Invited Paper) [1 1902-6]

\section{ADVANCED LASERS AND APPLICATIONS}

11902 Ol Ultra-narrow linewidth SOA fiber laser assisted by distributed self-injection feedbacks (Invited Paper) [11902-17]

SIGNAL PROCESSING

1190200 All-fiber flat-top orbital angular momentum mode converter realized by a SMF-based helical grating with phase modulation (Invited Paper) [11902-23]

PHOTONIC MEASUREMENT I

11902 OS Low-speed photonic sampling for self-referenced frequency response characterization of highspeed photodetectors [11902-27]

PHOTONIC MEASUREMENT II

11902 OW A photonic-assisted transceiver for microwave Doppler frequency shift measurement (Invited Paper) [11902-32] 
11902 OX Simultaneous three-dimensional measurement of temperature and velocity fields in swirling combustion (Invited Paper) [11902-33]

PHOTONIC MEASUREMENT III

$1190211 \quad$ Frequency response measurement of Mach-Zehnder modulators utilizing double carrier based on low frequency detection [11902-37]

POSTER SESSION

1190215 Reconfigurable photonic integrated computing chip based on quadrilateral MZI topology network [11902-40]

1190216 A $50 \mathrm{~km}$ fiber-optic two-way quantum time transfer experiment with long-term stability below 100 fs [11902-41]

1190217 A modified OAM Mach-Zehnder interferometer for displacement measurement [1 1902-42]

$1190218 \quad$ LFM-Costas waveform generation based on a Fourier domain mode locking optoelectronic oscillator [1 1902-43]

$119021 \mathrm{~A} \quad$ Real-time construction and control on dynamic systems [1 1902-45]

11902 1B Real-time identification of frequency-hopping millimeter-wave signals using photonic time stretch and reservoir computing [11902-46]

$119021 \mathrm{C}$ Anti-resonant reflecting guidance mechanism in ring-core fibers for the first-order orbital angular momentum modes generation [11902-47]

11902 1D Analysis of nebulization process based on multi-angle polarization scattering measurements [1 1902-48]

11902 1E Post-calibrated carrier envelope offset frequency for ultrafast dual-comb spectroscopy [1 1902-49]

$119021 \mathrm{~F} \quad$ Ultrafast tunable 16 channels integrated array DFB laser module [1 1902-50]

$119021 G \quad$ An improved signal filtering strategy based on EMD algorithm for ultrahigh precision grating encoder [11902-51]

$119021 \mathrm{H} \quad$ Multi-channel wavelength-swept DFB laser array based on REC technique [1 1902-52]

$119021 \mathrm{~J} \quad$ Ultrafast autocorrelator based on broadband radio frequency spectrum analyzer [11902-54] 